\title{
Soil biological attributes in pastures of different ages in a crop-livestock integrated system
}

\author{
Luciano Cavalcante Muniz ${ }^{(1)}$, Beata Emöke Madari(1), José Benedito de Freitas Trovo(2), \\ Ilka South de Lima Cantanhêde ${ }^{(3)}$, Pedro Luiz Oliveira de Almeida Machado ${ }^{(1)}$, Tarcísio Cobucci(1) \\ and Aldi Fernandes de Souza França(4)
}

\begin{abstract}
(1)Embrapa Arroz e Feijão, Rodovia GO-462, Km 12, Zona Rural, Caixa Postal 179, CEP 75375-000 Santo Antônio de Goiás, GO. E-mail: luciano-muniz@uol.com.br, madari@cnpaf.embrapa.br, pmachado@cnpaf.embrapa.br, cobucci@cnpaf.embrapa.br (2)Embrapa Recursos Genéticos e Biotecnologia, Parque Estação Biológica - PqEB, Av. W3 Norte (final), Caixa Postal 02372, CEP $70770-917$ Brasília, DF. E-mail: trovo@cnpaf.embrapa.br ${ }^{(3)}$ Instituto Federal do Maranhão, Campus Maracanã, Avenida dos Curiós, s/no, Vila Esperança, Caixa Postal 433, CEP 65095-460 São Luís, MA. E-mail: ilkacantanhede@ifma.edu.br ${ }^{(4)}$ Universidade Federal de Goiás, Escola de Veterinária, Itatiaia, Caixa Postal 131, CEP 74001-970 Goiânia, GO. E-mail: aldi@vet.ufg.br
\end{abstract}

\begin{abstract}
The objective of this work was to evaluate the effect of the pasture (Urochloa brizantha) component age on soil biological properties, in a crop-livestock integrated system. The experiment was carried out in a Brazilian savannah (Cerrado) area with 92 ha, divided into six pens of approximately 15 ha. Each pen represented a different stage of the pasture component: formation, $\mathrm{P} 0$; one year, $\mathrm{P} 1$; two years, $\mathrm{P} 2$; three years, $\mathrm{P} 3$; and final with 3.5 years, Pf. Samples were taken in the $0-10 \mathrm{~cm}$ soil depth. The soil biological parameters - microbial biomass carbon $(\mathrm{MBC})$, microbial biomass respiration $\left(\mathrm{C}-\mathrm{CO}_{2}\right)$, metabolic quotient $\left(\mathrm{qCO}_{2}\right)$, microbial quotient $\left(\mathrm{q}_{\mathrm{mic}}\right)$, and total organic carbon (TOC) - were evaluated and compared among different stages of the pasture, and between an adjacent area under native Cerrado and another area under degraded pasture (PCD). The MBC, $\mathrm{q}_{\mathrm{mic}}$ and TOC increased and $\mathrm{qCO}_{2}$ reduced under the different pasture stages. Compared to PCD, the pasture stages had higher MBC, $\mathrm{q}_{\text {mic }}$ and TOC, and lower $\mathrm{qCO}_{2}$. The crop-livestock integrated system improved soil microbiological parameters and immobilized carbon in the soil in comparison to the degraded pasture.
\end{abstract}

Index terms: metabolic quotient, microbial biomass carbon, microbial quotient, soil respiration.

\section{Atributos biológicos do solo em pastagens de diferentes idades no sistema de integração lavoura-pecuária}

\begin{abstract}
Resumo - O objetivo deste trabalho foi avaliar o efeito da idade do componente pastagem (Urochloa brizantha) sobre as propriedades biológicas do solo, em um sistema de integração lavoura-pecuária. O experimento foi realizado numa área de Cerrado, com 92 ha, dividida em seis piquetes de aproximadamente 15 ha. Cada piquete representou um estágio diferente do componente pastagem: em formação, P0; de um ano, P1; dois anos, P2; três anos, P3; e final de 3,5 anos, Pf. As amostras foram coletadas à profundidade de $0-10 \mathrm{~cm}$. As propriedades biológicas do solo - carbono da biomassa microbiana (CBM), respiração da biomassa mircobiana $\left(\mathrm{C}-\mathrm{CO}_{2}\right)$, quociente metabólico $\left(\mathrm{qCO}_{2}\right)$; quociente microbiano $\left(\mathrm{q}_{\mathrm{mic}}\right)$; e o carbono orgânico total $(\mathrm{COT})$ - foram avaliadas e comparadas entre as pastagens de diferentes idades, e entre uma área adjacente sob vegetação nativa de Cerrado e uma pastagem degradada (PCD). O CBM, o q mic e o COT aumentaram gradativamente, e o $\mathrm{qCO}_{2}$ diminuiu, nas pastagens de diferentes idades. Em comparação à PCD, o CBM, o q $\mathrm{q}_{\mathrm{mic}}$ e o COT foram maiores, e o $\mathrm{qCO}_{2}$ menor, nas pastagens. O sistema de integração lavoura-pecuária melhorou os parâmetros biológicos e imobilizou carbono no solo, em comparação à pastagem degradada.
\end{abstract}

Termos para indexação: quociente metabólico, carbono da biomassa microbiana, quociente microbiano, respiração do solo.

\section{Introduction}

The conservation or improvement of soil quality is essential for a sustainable production. Among the human-induced negative impacts on the environment, soil degradation is of main concern. Inappropriate land use can rapidly lead to organic matter depletion and, therefore, to alterations in soil physical, chemical and biological properties (Jakelaitis et al., 2008).

In natural ecosystems, there is a balance between soil cover and the soil physical, chemical and biological properties due to essential processes of nutrient cycling,

Pesq. agropec. bras., Brasília, v.46, n.10, p.1262-1268, out. 2011 
accumulation and decomposition of the organic matter. However, conventional agricultural activities such as monoculture of grains using conventional tillage, or even improved soil management systems like no-tillage with crop rotation, may lead to soil degradation (Denardin et al., 2008). Inappropriate pasture management also frequently promotes extensive changes in soil attributes that cause, in most cases, negative environmental impact (Silva et al., 2007).

In the last decade, the assessment of soil quality has received prominent attention. The quantification of changes in soil attributes, due to the intensification of land use and management systems, has been widely used to monitor the sustainable use of soils (Neves et al., 2007) and, consequently, the conservation of natural resources.The benefits of conservation agricultural systems on soil properties, as well as on grain and pasture yields, have been shown by various authors (Hungria et al., 2009; Boddey et al., 2010).

Ecosystem function depends mainly on soil microbial dynamics, which contributes to humus formation, nutrient cycling, physical structure, among other soil processes and characteristics. Soil microbial biomass, besides being a main agent of the transformation of organic materials in the soil, also acts as a reservoir of available nutrients to plants, with key participation in the biogeochemical cycles of agricultural interest (Moreira \& Malavolta, 2004).

According to Chaer \& Tótola(2007), microbiological indicators can be of great importance in the early evaluation of possible adverse effects of management on soil quality. They allow early adoption of corrective measures and the identification ongoing processes in the current management system.

Most studies on the Cerrado have been done to assess the effects of soil management and of annual crop production systems on soil biological attributes (Cardoso et al., 2009). However, there are few data (Carneiro et al., 2008) on the effects of Urochloa pastures under crop-livestock integrated system on these attributes.

The objective of this study was to evaluate the effect of rotation between annual crops and pastures on the soil biological properties, with emphasis on the pasture component in its different stages (age) of development.

\section{Materials and Methods}

The study was carried out at Capivara Farm, of Embrapa Arroz e Feijão, in Santo Antônio de Goiás, Goiás State, Brazil $\left(16^{\circ} 30^{\prime} \mathrm{S}, 44^{\circ} 17^{\prime} \mathrm{W}\right.$, and $823 \mathrm{~m}$ altitude).

According to Köppen's classification system, the experimental area has an Aw climate (tropical, megathermic savannah). The average annual air temperature is $23^{\circ} \mathrm{C}$; June has the lowest average minimum $\left(15.1^{\circ} \mathrm{C}\right)$, and September has the highest average maximum $\left(32.2^{\circ} \mathrm{C}\right)$. The rainfall regime is well defined, with a rainy season from October to April and dry season from May to September. The average annual rainfall is $1,487 \mathrm{~mm}$, and the relative average humidity of the air is $71 \%$; August is the driest month with $37.5 \%$.

The soil of the studied area was a Rhodic Ferralsol with a heavy clay texture (Food and Agriculture Organization of the United Nations, 1990). The correspondent classification of the soil by the Brazilian Soil Classification System (Santos et al., 2006) is Latossolo Vermelho acriférrico argiloso. The natural vegetation of the region is a broad-leaved evergreen forest and the major landform is plain (Food and Agriculture Organization of the United Nations, 2006), and the predominant clay mineral is kaolinite.

The experiment with the crop-livestock integrated system (CLIS) was carried out in a 92-ha area, divided into six pens of approximately 15 ha. The rotation between annual crops (2.5 years) and pasture (3.5 years) was characteristic of the Santa Fé system (Cobucci et al., 2001). The annual crop component included soybean (Glycine max), upland rice (Oryza sativa) and forage corn (Zea mays), combined with Urochloa as green manure in the rainy season and common bean (Phaseolus vulgaris) under irrigation in the dry season. The pasture component included the palisadegrass, Urochloa brizantha cv. Marandu (Syn. Brachiaria brizantha). The same rotation was used in all pens; however, the stage of the rotation was different for each pen at the time of evaluation (Table 1).

The rotation, repeated every six years, begun with soybean sown (October) in a no-till system, after the application of nonselective herbicide; fertilization was done with $495 \mathrm{~kg} \mathrm{ha}^{-1} \mathrm{NPK}$ (02-20-20). After soybean, irrigated common bean was sown (June) in no-till, with $105 \mathrm{~kg} \mathrm{ha}^{-1} \mathrm{P}$ and $48 \mathrm{~kg} \mathrm{ha}^{-1} \mathrm{~K}$. In the following year, the soil was prepared for upland rice cultivation

Pesq. agropec. bras., Brasília, v.46, n.10, p.1262-1268, out. 2011 
by plowing with a light disk harrow and application of $300 \mathrm{~kg} \mathrm{ha}^{-1}$ NPK (04-30-16) + micronutrients at sowing, in November, and $208 \mathrm{~kg} \mathrm{ha}^{-1}$ urea as top dressing. In the same year (dry season), irrigated common bean was cultivated again (June-September) in no-till. Then, before the pasture component, corn was cultivated in consortium with palisade grass (OctoberMarch). Before that, the soil was prepared using a light disk harrow and $464 \mathrm{~kg} \mathrm{ha}^{-1}$ NPK (04-30-16) + Zn at sowing, and $450 \mathrm{~kg} \mathrm{ha}^{-1}$ of ammonium sulphate as top dressing. After the corn harvesting (February-Abril), the pasture component was settled and kept for the following 3.5 years, without any soil management and fertilizer application during this period.

In 2007, 107 animals of Nelore breed were handled in the pens under evaluation. The average animal density was 2.4 livestock unit per hectare $\left(\mathrm{LU} \mathrm{ha}^{-1}\right)$, in the dry season, and 3.6 $\mathrm{LU} \mathrm{ha}^{-1}$ in the rainy season. In 2008, 133 Nelore animals were handled, with an

Table 1. Description of treatments during the two years of evaluation of the effects of ageing pastures (Urochloa brizantha) on the soil microbial attributes in a crop-livestock integrated system.

\begin{tabular}{llcccccccc}
\hline Year & Season & \multicolumn{8}{c}{ Pens $^{(1)}$} \\
\cline { 2 - 9 } & & 1 & 2 & 3 & 4 & 5 & 6 & 7 & 8 \\
\hline \multirow{2}{*}{2007} & May & P1 & P2 & P3 & P0 & PCD & Cerrado & - & - \\
& October & P2 & P3 & Pf & P1 & PCD & Cerrado & - & - \\
2008 & May & P2 & P3 & $-{ }^{(2)}$ & P1 & PCD & Cerrado & - & P0 \\
October & P3 & Pf & - & P2 & PCD & Cerrado & - & P1 \\
\hline
\end{tabular}

(1) PCD, degraded pasture; $\mathrm{P} 0$, pasture formation; $\mathrm{P} 1$, one-year pasture; $\mathrm{P} 2$, two-year pasture; P3, three-year pasture; Pf, 3.5-year pasture (final, after the nonselective herbicide spraying). ${ }^{(2)}$ No soil sampling since the areas were occupied with annual crops. average density of $1.2 \mathrm{LU} \mathrm{ha}^{-1}$ in the dry season and 2.7 $\mathrm{LU} \mathrm{ha}^{-1}$ in the rainy season. In the degraded pasture, animals were managed under continuous grazing, with an average $0.85 \mathrm{LU} \mathrm{ha}^{-1}$ in the dry season and $1 \mathrm{LU} \mathrm{ha}^{-1}$ in the rainy season.

The experiment was evaluated in its sixth year, with all areas closing a whole cycle, although at different stages of the rotation. Each stage was present in a different pen, hence the different stages existed in a parallel manner at the time of the evaluation.

The pastures were evaluated in five different stages: pasture formation ( $\mathrm{P} 0)$, which consisted of the remaining palisadegrass after the corn harvest; first year pasture (P1); second year pasture (P2); third year pasture $(\mathrm{P} 3)$; and final pasture $(\mathrm{Pf})$, which consisted of pasture in its final stage, with 3.5 years, after a nonselective herbicide spraying in order to initiate the crop component again. Degraded pasture (PCD) and the native savannah (Cerrado) controls were located in areas neighboring the experiment.

Soil fertility attributes and soil textural class are presented in Table 2. Samples were taken at $0-10 \mathrm{~cm}$ depth, and four combined samples per treatment (pen) were made from 20 individual samples, at the end of each season (May and October, 2007 and 2008). Samples were stored in the refrigerator at $4^{\circ} \mathrm{C}$ for a maximum of six months until further analyses. All biological analyses were done at the Centro de Análise Agroambiental of Embrapa Arroz e Feijão.

The microbial biomass carbon (MBC) was measured by fumigation-extraction method, as described by Vance et al. (1987), and the soil basal respiration rate $\left(\mathrm{C}-\mathrm{CO}_{2}\right)$ was determined according to Anderson \& Domsch (1993). The metabolic $\left(\mathrm{qCO}_{2}\right)$ and microbial quotient

Table 2. Fertility attributes and granulometric composition in the $0-10 \mathrm{~cm}$ depth of the Rhodic Ferralsol under savannah vegetation (Cerrado), degraded pasture (PCD) and crop-livestock integrated system with pasture components of different ages (P0-Pf).

\begin{tabular}{|c|c|c|c|c|c|c|c|c|c|c|c|c|c|c|c|c|}
\hline Area $^{(1)}$ & $\begin{array}{l}\mathrm{SOM}^{(2)} \\
\left(\mathrm{g} \mathrm{dm}^{-3}\right)\end{array}$ & $\begin{array}{c}\mathrm{pH} \\
\left(\mathrm{H}_{2} \mathrm{O}\right)\end{array}$ & $\begin{array}{c}\mathrm{Ca} \\
----- \\
\end{array}$ & $\begin{array}{l}\mathrm{Mg} \\
(\mathrm{cmol}\end{array}$ & $\begin{array}{c}\text { Al } \\
\left.m^{-3}\right)-\end{array}$ & H+Al & P & K & $\mathrm{Cu}$ & $\begin{array}{r}\mathrm{Zn} \\
\left.\mathrm{dm}^{-3}\right)\end{array}$ & $\mathrm{Fe}$ & $\mathrm{Mn}$ & Clay & Silt & Sand & Textural class $^{(3)}$ \\
\hline Cerrado & 19.2 & 5.0 & 0.21 & 0.13 & 0.7 & 7.02 & 1.0 & 31.8 & 2.0 & 0.7 & 18.2 & 63.5 & 709 & 67 & 224 & Heavy clay \\
\hline PCD & 10.0 & 5.7 & 0.48 & 0.22 & 0.1 & 4.18 & 0.5 & 25.0 & 1.6 & 0.6 & 4.1 & 47.8 & 514 & 26 & 460 & Sandy clay \\
\hline $\mathrm{P} 0$ & 13.7 & 5.6 & 1.68 & 0.63 & 0.1 & 4.75 & 17.6 & 115.5 & 2.3 & 3.7 & 27.4 & 43.4 & 579 & 97 & 324 & Clay \\
\hline P1 & 13.8 & 5.4 & 0.82 & 0.34 & 0.1 & 4.78 & 10.3 & 63.8 & 1.6 & 4.1 & 10.6 & 34.6 & 599 & 97 & 304 & Heavy clay \\
\hline P2 & 13.8 & 5.5 & 0.98 & 0.39 & 0.1 & 4.51 & 5.5 & 63.5 & 1.6 & 2.5 & 17.7 & 33.5 & 709 & 80 & 211 & Heavy clay \\
\hline P3 & 14.5 & 5.8 & 1.43 & 0.58 & 0.1 & 3.80 & 3.9 & 51.3 & 2.0 & 2.1 & 25.7 & 38.9 & 596 & 100 & 304 & Heavy clay \\
\hline Pf & 14.1 & 5.6 & 1.04 & 0.49 & 0.1 & 4.21 & 3.8 & 58.8 & 2.2 & 2.2 & 29.5 & 60.2 & 659 & 50 & 291 & Heavy clay \\
\hline
\end{tabular}

(1) PCD, degraded pasture; P0, pasture formation; P1, one-year pasture; P2, two-year pasture; P3, three-year pasture; Pf, 3.5-year pasture (final, after the nonselective herbicide spraying). ${ }^{(2)}$ SOM, soil organic matter. ${ }^{(3)}$ (Food and Agriculture Organization of the United Nations, 2006). 
$\left(\mathrm{q}_{\text {mic }}\right)$ were also calculated. The $\mathrm{qCO}_{2}$ is the amount of $\mathrm{C}-\mathrm{CO}_{2}$ produced per unit of soil microbial biomass per unit of time ( $\mathrm{mg} \mathrm{g}^{-1}$ per hour), as described by Anderson \& Domsch (1993). The $\mathrm{q}_{\mathrm{mic}}$ is the ratio between the microbial carbon $(\mathrm{MBC})$ and the total organic carbon [(MBC/TOC)100] and provides information about the organic matter quality (Powlson et al., 1997).

Soil total organic carbon (TOC) was obtained according to Walkley-Black method (Silva, 2009), without multiplying with the factor 1.724. The theoretical basis for the use of this factor is that in the mean humus composition, carbon participates with $58 \%$. However, in the present work, we chose to use the directly measured dichromate-oxidable $\mathrm{C}$ instead of the indirect soil organic measure (SOM) obtained with the factor.

The TOC represents only a fraction of the soil organic C. Another fraction is related to organic $\mathrm{C}$ that is not oxidized by potassium dichromate, and represents $\mathrm{C}$ in more stable structures, inert in the soil, such as black carbon or charcoal, which may be present in large amounts in the soils of the Brazilian Cerrado. Some estimates account for up to $40 \%$ TOC in this form (Jantalia et al., 2007). Nevertheless, this C is highly refractory and largely inert, and is not expected to be influenced by soil management practices in the short or medium terms.

Data analysis were performed using SAS software (SAS Institute, 1986) with the Proc GLM procedure, and means were compared by Tukey test, at 5\% probability. The model consisted of the nested effect of soil depth within each treatment. Data were further analyzed using Proc Corr (Pearson's bivariate correlation) of SAS software.

\section{Results and Discussions}

Microbial biomass increased according to the pasture (stage) ageing, up to P3 stage (Table 3), which had the highest values among all treatments, including the area under native vegetation (Cerrado). The smallest MBC value was found in the degraded pasture.

According to Bayer \& Mielniczuk (2008), the organic matter content of a soil under natural vegetation is in equilibrium; however, under agricultural use, it tends to diminish drastically, specially when intensive soil tillage is practiced combined with low levels of plant residue addition. Silva et al. (2007) observed that MBC values were lower in soil under no-till or conventional tillage, in comparison to soil under native forest (576 mg kg-1). Cardoso et al. (2009) assessed changes in soil biological properties, after the replacement of forest by pasture at different ages of formation and, contrary to the results of the present study, they observed substantial reductions in $\mathrm{MBC}$ in managed pastures, in comparison to the forest.

Nevertheless, Carneiro et al. (2008) reported an increase of approximately $50 \%$ in the value of MBC in pastures formed by Urochloa decumbens and in CLIS, in comparison to the native savannah vegetation (Cerrado). According to the authors, the abundant root system of the pasture provided a great amount of carbon that stimulated soil microbes.

The result obtained for MBC showed similarity with the ones obtained for $\mathrm{q}_{\text {mic }}$ (Table 3). A state of equilibrium in $\mathrm{q}_{\text {mic }}$ may be considered when values are between two and five, meaning that 2 to $5 \%$ of soil carbon is composed of microorganisms (Jenkinson \& Ladd, 1981). According to this observation, all treatments were within this range, and even the degraded pasture was at its lower limit (2.01\%). During the experiment period, there was an increase in the $\mathrm{q}_{\text {mic }}$ from $\mathrm{P} 0$ to $\mathrm{P} 3$, suggesting that the well-established and aging pasture enhanced microbial life in the soil. Parfitt et al. (2010) reported that high input grazing systems, that include urea application, reduced the $\mathrm{q}_{\text {mic }}$ in New Zealand pastures. In the present study, urea and other $\mathrm{N}$-synthetic fertilizers were applied only on the annual crop production component of CLIS, and no fertilizer

Table 3. Soil biological parameters $(0-10 \mathrm{~cm})$ obtained in a crop-livestock integrated system with pasture component of different ages $(\mathrm{P} 0-\mathrm{Pf})^{(1)}$.

\begin{tabular}{lccccc}
\hline Area $^{(2)}$ & \multicolumn{5}{c}{ Parameter $^{(3)}$} \\
\cline { 2 - 6 } & $\mathrm{C}-\mathrm{CO}_{2}$ & $\mathrm{MBC}$ & $\mathrm{qCO}_{2}$ & $\mathrm{TOC}$ & $\mathrm{q}_{\text {mic }}$ \\
\hline Cerrado & $1.56 \mathrm{cb}$ & $337.80 \mathrm{~b}$ & $5.03 \mathrm{bc}$ & $14.03 \mathrm{a}$ & $2.41 \mathrm{~b}$ \\
PCD & $0.61 \mathrm{~d}$ & $159.30 \mathrm{c}$ & $4.44 \mathrm{~cd}$ & $7.94 \mathrm{~d}$ & $2.01 \mathrm{c}$ \\
P0 & $2.51 \mathrm{a}$ & $271.40 \mathrm{~b}$ & $9.27 \mathrm{a}$ & $9.89 \mathrm{c}$ & $2.74 \mathrm{~b}$ \\
P1 & $1.79 \mathrm{~b}$ & $294.90 \mathrm{~b}$ & $5.94 \mathrm{~b}$ & $10.78 \mathrm{bc}$ & $2.73 \mathrm{~b}$ \\
P2 & $1.39 \mathrm{bc}$ & $323.80 \mathrm{~b}$ & $4.49 \mathrm{bc}$ & $11.40 \mathrm{bc}$ & $2.84 \mathrm{~b}$ \\
P3 & $1.09 \mathrm{~cd}$ & $454.60 \mathrm{a}$ & $2.40 \mathrm{~d}$ & $10.26 \mathrm{bc}$ & $4.43 \mathrm{a}$ \\
Pf & $0.51 \mathrm{~d}$ & $441.90 \mathrm{a}$ & $1.23 \mathrm{~d}$ & $11.72 \mathrm{~b}$ & $3.77 \mathrm{a}$ \\
\hline CV $(\%)$ & 41.02 & 24.65 & 43.67 & 11.77 & 31.46 \\
\hline
\end{tabular}

(1) Means followed by equal letters do not differ by Tukey's test, at $5 \%$ probability. (2) $\mathrm{PCD}$, degraded pasture; $\mathrm{P} 0$, pasture formation; $\mathrm{P} 1$, one-year pasture; P2, two-year pasture; $\mathrm{P}$, three-year pasture; Pf, 3.5-year pasture (final, after the nonselective herbicide spraying). ${ }^{(3)} \mathrm{C}-\mathrm{CO}_{2}$, microbial biomass respiration ( $\mathrm{g} \mathrm{kg}^{-1}$ per hour); $\mathrm{MBC}$, microbial biomass carbon $\left(\mathrm{mg} \mathrm{kg}^{-1}\right)$; $\mathrm{qCO}_{2}$, metabolic quotient ( $\mathrm{mg} \mathrm{g}^{-1}$ per hour); TOC, total organic carbon $\left(\mathrm{g} \mathrm{kg}^{-1}\right) ; \mathrm{q}_{\text {mic }}$, microbial quotient (\%). 
was added to the soil during the settlement of pasture. Frazão et al. (2010) also measured the highest microbial $\mathrm{C}$ and $\mathrm{N}$ concentrations in the Cerrado and in pasture areas, in comparison to conventionally managed soils and soil under no-tillage. The permanent soil cover and the lack of soil disturbance by agricultural practices allowed more favorable conditions for microbial development in pastures and in Cerrado.

According to Stenberg (1999), soils which maintain a high amount of microbial biomass are able not only to store but also to cycle more nutrients. This, at the same time, also makes them more sensitive to changes in its soil quality. The relatively low $\mathrm{q}_{\text {mic }}$ in the degraded pasture can probably be explained by the low quantity and quality of its organic matter. Under stress condition, the capability of utilization of carbon may be decreased and, in this case, $\mathrm{q}_{\text {mic }}$ decreases (Gama-Rodrigues \& Gama-Rodrigues, 2008).

The greatest value for microbial respiration $\left(\mathrm{C}-\mathrm{CO}_{2}\right)$ in the soil was measured in the pasture in its introductory stage (Table 3 ), and this value decreased with the evolvement of the pasture up to Pf. The respiration found for the soil under Cerrado and for the degraded pasture was between the maximum values, observed in $\mathrm{P} 0$, and the minimum ones observed in Pf. The microbial biomass respiration can be influenced by several factors. Therefore, its independent assessment is quite complicated, however, the combination of this parameter with $\mathrm{MBC}$ results in another meaningful microbial activity index - the metabolic quotient $\left(\mathrm{qCO}_{2}\right)$. This index is the proportion of $\mathrm{CO}_{2}$ evolved (respired) by $\mathrm{MBC}$ unit per unit of time, and it is very used to detect stressful conditions for microbial biomass, since high $\mathrm{qCO}_{2}$ reflects a high demand for organic C (Anderson et al., 2010). As the microbial biomass becomes more efficient in using the resources of the ecosystem, less carbon is lost through respiration and higher proportions of carbon are fixed to microbial tissues (Tótola \& Chaer, 2002). The largest value for $\mathrm{qCO}_{2}$, similarly to microbial respiration, was found in the pasture in its introductory stage, and the lowest was detected in the pasture in its final stage. The values found for the Cerrado and for degraded pasture stood between those of pasture in the introductory and final stages.

Increased microbial activity in pasture environments in comparison to native vegetation has been reported in the literature (Carneiro et al., 2008) and attributed to intense growth and cycling of grass root system in the topsoil. Souza et al. (2008) found no significant effect of grazing intensities on $\mathrm{qCO}_{2}$ in a CLIS. They attributed this result to the low percentage of catabolically active microbial biomass.

Considering all treatments, there was a nonsignificant negative correlation $(\mathrm{r}=-0.6202, \mathrm{p}=0.1373)$ between soil $\mathrm{pH}$ and $\mathrm{qCO}_{2}$ (Figure 1). Low $\mathrm{pH}$ can limit both microbial population growth and activity, and represents a stress factor (Siqueira \& Moreira, 1997). Thus, increases in $\mathrm{pH}$ are thought to lower $\mathrm{qCO}_{2}$. When only the different pasture stages were considered, the correlation between $\mathrm{pH}$ and $\mathrm{qCO}_{2}$ became pronounced $(\mathrm{r}=-0.9155 ; \mathrm{p}=0.0291)$. The increase of $\mathrm{pH}$, during the aging of the pasture in CLIS (Table 1), may be attributed to the reduction of the acidifying effect of nitrogen fertilization applied during the annual crop cultivation. Another reason for that may be related to recycling of basic reaction nutrients by the pasture, mainly $\mathrm{Ca}$ and Mg (Table 2). Enwall et al. (2007) attributed the correlation between microbial respiration (activity) and soil acidity to a response to fertilization, to primarily nitrogen, and then to sewage sludge application. Nevertheless, the greater respiration rate in the early

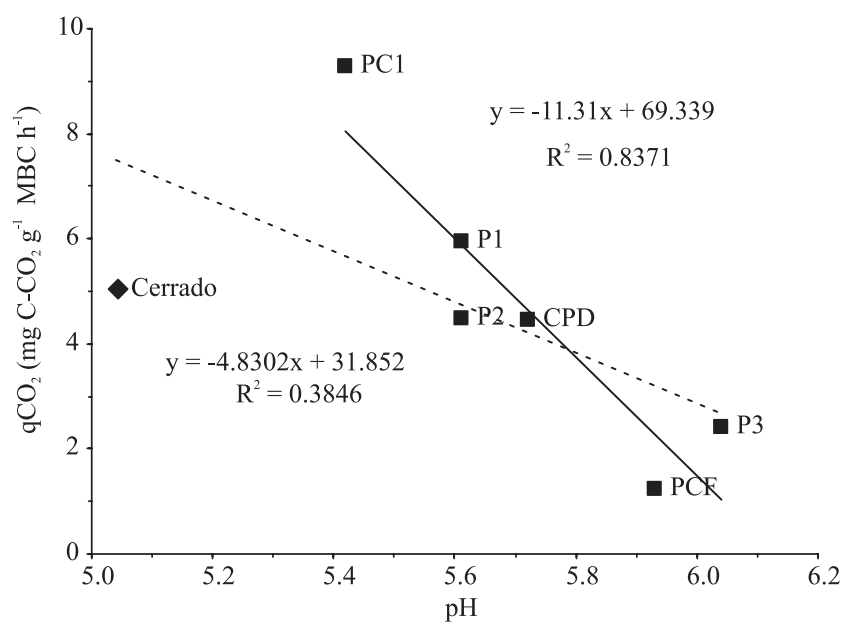

Figure 1. $\mathrm{pH}$ versus $\mathrm{qCO}_{2}$ considering all studied areas (....), and only the different stages of the pasture in CLIS (-), excluding Cerrado and degraded pasture (CPD). Cerrado: Soil under native vegetation; PCD: Soil under degraded pasture; PCI: Soil under pasture in its initial stage, after the harvest of corn in ICL; P1: Soil under pasture of one year of establishment in ICL; P2: Soil under pasture of two years of establishment in ICL; P3: Soil under pasture of three years of establishment in ICL; PCF: Soil after non-selective herbicide spraying on pasture for direct drilling in ICL (pasture in its final stage, of 3.5 years of establishment). 
stage of the pasture ( $\mathrm{P} 0)$ may have been induced by the input of organic matter through the establishment of the palisade grass (mainly root system and leaves), in association with corn, which may have caused a sort of mulching effect as reported by Wardle et al. (1999). During the experiment, this effect tends to decrease and reach an equilibrium. To get this equilibrium, less $\mathrm{C}$ is lost from the soil through microbial respiration, which may have contributed to the buildup observed in TOC. In the Brazilian Cerrado, Carneiro et al. (2008) compared different soil management systems and natural ecosystems, and reported that only pasture provided improvements in the biological soil attributes ( $\mathrm{MBC}, \mathrm{C}-\mathrm{CO}_{2}, \mathrm{qCO}_{2}, \mathrm{q}_{\text {mic }}$ ), with CLIS in its pasture component included. Finally, Moscatelli et al. (2007) observed higher production of $\mathrm{CO}_{2}$ in soils under agricultural production and lower $\mathrm{CO}_{2}$ under pasture.

\section{Conclusions}

1. The biological attributes of the soil are gradually improved during the development (aging) of the pasture component of a crop-livestock integrated system.

2. The soil in a crop-livestock integrated system is able to maintain higher levels of organic carbon than under degraded pasture and has lower organic carbon levels than under natural forest vegetation.

3. The replacement of degraded pastures by a crop-livestock integrated system enhances the soil environment in favor of both absolute (MBC) and relative $\left(\mathrm{q}_{\text {mic }}\right)$ microbial population growth, and decreases environmental stress $\left(\mathrm{qCO}_{2}\right)$ on the microbial population.

\section{Acknowledgements}

To the MSc. student Ecion Rosa de Oliveira of the Universidade Federal de Goiás, for his help in the laboratory analyses; and to Financiadora de Estudos e Projetos and to Embrapa, for financial support.

\section{References}

ANDERSON, T.H.; DOMSCH K.H. Soil microbial biomass: the eco-physiological approach. Soil Biology and Biochemistry, v.42, p.2039-2043, 2010.

ANDERSON, T.H.; DOMSCH, K.H. The metabolic quotient for $\mathrm{CO}_{2}\left(q \mathrm{CO}_{2}\right)$ as a specific activity parameter to assess the effects of environmental conditions, such as $\mathrm{pH}$, on the microbial biomass of forest soils. Soil Biology and Biochemistry, v.25, p.393-395, 1993.

BAYER, C.; MIELNICZUK, J. Dinâmica e função da matéria orgânica. In: SANTOS, G. deA.; SILVA, L.S. da; CANELLAS, L.P.; CAMARGO, F.A. de O. (Ed.). Fundamentos da matéria orgânica do solo: ecossistemas tropicais e subtropicais. 2.ed. rev. atual. Porto Alegre: Metrópole, 2008. p.7-18.

BODDEY, R.M.; JANTALIA, C.P.; CONCEIÇÃO, P.C.; ZANATTA, J.A.; BAYER, C.; MIELNICZUK, J.; DIECKOW, J.; SANTOS, H.P. dos; DENARDIN, J.E.; AITA, C.; GIACOMINI, S.; ALVES, B.J.R.; URQUIAGA, S. Carbon accumulation at depth in Ferralsols under zero-till subtropical agriculture. Global Change Biology, v.16, p.784-795, 2010.

CARDOSO, E.L.; SILVA, M.L.N.; MOREIRA, F.M. de S.; CURI, N. Atributos biológicos indicadores da qualidade do solo em pastagem cultivada e nativa no Pantanal. Pesquisa Agropecuária Brasileira, v.44, p.631-637, 2009.

CARNEIRO, M.A.C.; ASSIS, P.C.R.; MELO, L.B. de C.; PERREIRA, H.S.; PAULINO, H.B.; SILVEIRA NETO, A.N. da. Atributos bioquímicos em dois solos de Cerrado sob diferentes sistemas de manejo e uso. Pesquisa Agropecuária Tropical, v.38, p.276-283, 2008.

CHAER. G.M.; TÓTOLA, M.R. Impacto do manejo de resíduos orgânicos durante a reforma de plantios de eucalipto sobre indicadores de qualidade do solo. Revista Brasileira de Ciência do Solo, v.31, p.1381-1396, 2007.

COBUCCI, T.; KLUTHCOUSKI, J.; ADAIR, H. Sistema Santa Fé: produção de forragem na entressafra. In: WORKSHOP INTERNACIONAL PROGRAMA DE INTEGRAÇÃO AGRICULTURA E PECUÁRIA PARA O DESENVOLVIMENTO SUSTENTÁVEL DAS SAVANAS TROPICAIS SULAMERICANAS, 2001, Santo Antônio de Goiás. Anais. Santo Antônio de Goiás: Embrapa Arroz e Feijão, 2001. p.125-135. (Embrapa Arroz e Feijão. Documentos, 123).

DENARDIN, J.E.; KOCHHANN, R.A.; SANTI,A.; FAGANELLO, A.; SATTLER, A. Efeito da consorciação milho-braquiária (Brachiaria brizantha) na mitigação da compactação do solo. Passo Fundo: Embrapa Trigo, 2008. 13p. (Embrapa Trigo. Boletim de pesquisa e desenvolvimento, 54).

ENWALL, K.; NYBERG, K.; BERTILSSON, S.; CEDERLUND, J.S.; HALLIN, S. Long-term impact of fertilization on activity and composition of bacterial communities and metabolic guilds in agricultural soil. Soil Biology \& Biochemistry, v.39, p.106-115, 2007.

FOOD AND AGRICULTURE ORGANIZATION OF THE UNITED NATIONS. Guidelines for soil description. $4^{\text {th }}$ ed. Rome: FAO, 2006. 97p.

FOOD AND AGRICULTURE ORGANIZATION OF THE UNITED NATIONS. Soil map of the world. Rome: FAO, 1990. 119p.

FRAZÃO, L.A.; PICCOLO, M. de C.; FEIGL, B.J.; CERRI, C.C.; CERRI, C.E.P. Inorganic nitrogen, microbial biomass and microbial activity of a sandy Brazilian Cerrado soil under different land uses. Agriculture, Ecosystems and Environment, v.135, p.161-167, 2010. 
GAMA-RODRIGUES, E.F. da; GAMA-RODRIGUES, A.C. da. Biomassa microbiana e ciclagem de nutrientes. In: SANTOS, G. de A.; SILVA, L.S. da; CANELLAS, L.P.; CAMARGO, F.A. de O. (Ed.). Fundamentos da matéria orgânica do solo: ecossistemas tropicais e subtropicais. 2.ed. rev. atual. Porto Alegre: Metrópole, 2008. p.159-170.

HUNGRIA, M.; FRANCHINI, J.C.; BRANDÃO-JUNIOR, O.; KASCHUK, G.; SOUZA, R.A. Soil microbial activity and crop sustainability in a long-term experiment with three soil-tillage and two crop-rotation systems. Applied Soil Ecology, v.42, p.288-296, 2009

JAKELAITIS, A.; SILVA, A.A. da; SANTOS, J.B. dos; VIVIAN, R. Qualidade da camada superficial de solo sob mata, pastagens e áreas cultivadas. Pesquisa Agropecuária Tropical, v.38, p.118-127, 2008.

JANTALIA, C.P.; RESCK, D.V.S.; ALVES, B.J.R.; ZOTARELLI, L.; URQUIAGA, S.; BODDEY, R.M. Tillage effect on $\mathrm{C}$ stocks of a clayey Oxisol under a soybean-based crop rotation in the Brazilian Cerrado region. Soil and Tillage Research, v.95, p.97-109, 2007.

JENKINSON, D.S.; LADD, J.N. Microbial biomass in soil: measurement and turnover. In: PAUL, E.A.; LADD, J.N. (Ed.). Soil biochemistry. New York: Marcel Dekker, 1981. p.415-471. (Books in soils and the environment, 5).

MOREIRA, A.; MALAVOLTA, E. Dinâmica da matéria orgânica e da biomassa microbiana em solo submetido a diferentes sistemas de manejo na Amazônia Ocidental. Pesquisa Agropecuária Brasileira, v.39, p.1103-1110, 2004.

MOSCATELLI, M.C.; DI TIZIO, A.; MARINARI, S.; GREGO, S. Microbial indicators related to soil carbon in Mediterranean land use systems. Soil and Tillage Research, v.97, p.51-59, 2007.

NEVES, C.M.N. das; SILVA, M.L.N.; CURI, N.; CARDOSO, E.L.; MACEDO, R.L.G.; FERREIRA, M.M.; SOUZA, F.S. de. Atributos indicadores da qualidade do solo em sistema agrossilvopastoril no noroeste do Estado de Minas Gerais. Scientia Forestalis, n.74, p.45-53, 2007.

PARFITT, R.L.; YEATES, G.W.; ROSS, D.J.; SCHON, N.L.; MACKAY, A.D.; WARDLE, D.A. Effect of fertilizer, herbicide and grazing management of pastures on plant and soil communities. Applied Soil Ecology, v.45, p.175-186, 2010.

POWLSON, D.S.; BROOKES, P.C.; CHRISTENSEN, B.T. Measurement of soil microbial biomass provides an early indication of changes in total soil organic matter due to straw incorporation. Soil Biology and Biochemistry, v.19, p.159-164, 1997.
SANTOS, H.G. dos; JACOMINE, P.K.T.; ANJOS, L.H.C. dos; OLIVEIRA, V.A. de; OLIVEIRA, J.B. de; COELHO, M.R.; LUMBRERAS, J.F.; CUNHA, T.J.F. (Ed.). Sistema brasileiro de classificação de solos. 2.ed. Rio de Janeiro: Embrapa Solos, 2006. 306p.

SAS INSTITUTE. SAS/STAT procedure guide for personal computers. Version 6. Cary: SAS Institute, 1986. 846p.

SILVA, F.C. da (Ed.). Manual de análises químicas de solos, plantas e fertilizantes. 2.ed. Brasília: Embrapa Informação Tecnológica; Rio de Janeiro: Embrapa Solos, 2009. 627p.

SILVA, M.B. da; KLIEMANN, H.J.; SILVEIRA, P.M. da; LANNA, A.C. Atributos biológicos do solo sob influência da cobertura vegetal e do sistema de manejo. Pesquisa Agropecuária Brasileira, v.42, p.1755-1761, 2007.

SIQUEIRA, J.O.; MOREIRA, F.M.S. Microbial populations and activities in highly-weathered acidic soils: highlights of the Brazilian research. In: MONIZ, A.C.; FURLANI, A.M.C.; SCHAFFERT, R.E.; FAGERIA, N.K.; ROSOLEM, C.A.; CANTARELLA, H. (Ed.). Plant-soil interactions at low $\mathbf{p H}$ : sustainable agriculture and forestry production. Campinas: Brazilian Soil Science Society, 1997. p.139-156.

SOUZA, E.D. de; COSTA, S.E.V.G. de A.; LIMA, C.V.S. de; ANGHINOMI, I.; MEURER, E.J.; CARVALHO, P.C. de F. Carbono orgânico e fósforo microbiano em sistema de integração agricultura-pecuária submetido a diferentes intensidades de pastejo em plantio direto. Revista Brasileira de Ciência do Solo, v.32, p.1273-1282, 2008.

STENBERG, B. Monitoring soil quality of arable land: microbiological indicators. Acta Agriculturae Scandinavica Section B - Soil and Plant Science, v.49, p.1-24, 1999.

TÓTOLA, M.R.; CHAER, G.M. Microrganismos e processos microbiológicos como indicadores de qualidade dos solos. In: ALVAREZ V., V.H.; SCHAEFER, C.E.G.R.; BARROS, N.F. de; MELLO, J.W.V. de; COSTA, L.M. da. (Ed.). Tópicos em ciência do solo. Viçosa: Sociedade Brasileira de Ciência do Solo, 2002. v.1, p.195-276.

VANCE, E.D.; BOOKES, P.C.; JENKINSON, D.S. An extraction method for measuring soil microbial biomass C. Soil Biology and Biochemistry, v.19, p.703-707, 1987.

WARDLE, D.A.; YEATES, G.W.; NICHOLSON, K.S.; BONNER, K.I.; WATSON, R.N. Response of soil microbial biomass dynamics, activity and plant litter decomposition to agricultural intensification over a seven-year period. Soil Biology and Biochemistry, v.31, p.1707-1720, 1999. 